\title{
POTENSI EKSTRAK N-HEKSAN, DIKLOROMETANA, ETIL ASETAT, DAN ETANOL 70\% JAMUR DEWA (Agaricus blazei Murill) TERHADAP SEL MCF-7
}

\author{
Misgiati $^{1}$ \\ ${ }^{1}$ Akademi Analis Farmasi dan Makanan Putra Indonesia Malang \\ Email Korespondensi : faiz219@yahoo.co.id
}

\begin{abstract}
ABSTRAK
Jamur dewa merupakan pangan fungsional. yang mempunyai aktivitas farmokalogi, Kandungan metabolit skunder mempunyai aktivitas sebagai antikanker. Tujuan penelitian ini untuk uji pendahuluan untuk mendapatkan bahan aktif yang mampu mempunyai aktivitas antikanker sel MCF-7. Tahapan penelitiannya ekstraksi bertingkat dengan beberapa pelarut. Ekstraksi menggunakan metode maserasi. Ekstrak yang dihasilkan diidentifikasi dan diuji aktivitas antikanker sel MCF-7. Identifikasi menggunakan metode KLT. Fase diam dengan silica GF254, fase geraknya nheksana:etilasetat. Uji aktivitas antikanker menggunakan metode MTT. Hasil identifikasi masing masing ekstrak mengandung metabolit skunder terpenoid. Aktivitas antikanker sel MCF-7 dengan IC $_{50}$ ekstrak n-heksana $15.0923 \mu \mathrm{g} / \mathrm{ml}$, ekstrak diklorometana $17.4213 \mu \mathrm{g} / \mathrm{ml}$, ekstrak etil asetat $10.9132 \mu \mathrm{g} / \mathrm{ml}$ dengan kriteria strong cytotoxicity sedangkan untuk ekstrak etanol $\mathrm{IC}_{50} 675,1236 \mu \mathrm{g} / \mathrm{ml}$.
\end{abstract}

Kata kunci : Jamur dewa, ekstraksi bertingkat, sel MCF-7 


\title{
POTENTIAL EXTRACTS OF N-HEXANE, DICHLOROMETHANE, ETHYL ACETATE, AND 70\% ETHANOL OF DEWA MUSHROOMS (Agaricus blazei Murill) ON MCF-7 CELLS
}

\begin{abstract}
God mushroom is a functional food. It has pharmacological activity. This content has activity as an anticancer. The purpose of this study was to conduct a preliminary test to obtain an active ingredient capable of having anticancer activity on MCF-7 cells. The stages of the research are stratified extraction with several solvents. Extraction using maceration. The resulting extract was identified and tested for the anticancer activity of MCF-7 cells. The test uses the TLC method. The stationary phase with silica GF254, the mobile phase is n-hexane: ethyl acetate. Anticancer activity test using the MTT method. The results of the identification of each extract contained terpenoid secondary metabolites. Anticancer activity of MCF-7 cells with IC50 extract of n-hexane $15.0923 \mu \mathrm{g} / \mathrm{ml}$, dichloromethane extract $17.4213 \mu \mathrm{g} / \mathrm{ml}$, ethyl acetate extract $10.9132 \mu \mathrm{g} / \mathrm{ml}$ with strong cytotoxicity criteria, while for ethanol extract IC50 $675,1236 \mu \mathrm{g} / \mathrm{ml}$.
\end{abstract}

Keywords: Jamur Dewa, extraction levels, MCF-7 cells

\section{PENDAHULUAN}

Kanker payudara merupakan

tertinggi untuk perempuan adalah jenis kanker kedua terbanyak pada wanita di seluruh dunia dan di kanker payudara yaitu sebesar 42,1 per Indonesia. Kanker payudara paling 100.000 penduduk dengan rata-rata sering ditemukan setelah kanker mulut rahim. Data terbaru dari American Cancer Society selama tahun 2021 terdapat 284.200 kasus kanker payudara pada wanita dan pria. Sedangkan data pada tahun 2018 kejadian kanker kematian 17 per 100.000 penduduk (Depkes RI, 2019). Pengobatan konvensional yang umum dilakukan dengan pembedahan, kemoterapi dan radioterapi. Pengobatan kanker secara pembedahan tidak dapat dilakukan khususnya pada sel kanker yang telah https://doi.org/10.33759/jrki.v4i1.231 
menyebar (metastasis). Sementara pengobatan kemoterapi dan radiasi dapat menimbulkan efek samping, yaitu dapat membunuh sel selain sel kanker. Usaha pencarian obat antikanker dari bahan alam yang mempunyai target molekuler yang spesifik, selektifitas yang tinggi, dan efek samping minimum, amat diperlukan dalam pengobatan penyakit kanker.

Jamur dewa (Agaricus blazei Murill) merupakan jamur makroskopis dapat digunakan sebagai pangan fungsional dan mempunyai aktivitas sebagai antikanker, antihipertensi, antikolesterol, antivirus, antidiabetik, antioksidan, antibakteri, dan imunostimulan (Shimizu et al., 2016)( Misgiati $\mathrm{M} \&$ Corebima AD, 2015)(Misgiati et al., 2021). Aktivitas tersebut berdasarkan penelitian secara in vitro maupun in vivo. Penelitian jamur dewa sebagai antikanker secara in vitro sudah banyak dilakukan, yaitu terhadap sel darah putih U937, MOLT4, HL-60, dan K-562 dengan $\mathrm{IC}_{50}$ 2.7; 9.4; 13.0; dan $16.0 \mu \mathrm{g} / \mathrm{mL}$ (Akiyamaa \& et al, 2011), sel tulang (HOS cell line) dengan $\mathrm{IC}_{50} 100 \mu \mathrm{g} / \mathrm{mL}$ (Wu et al., 2012), sel prostat DU145 dan PC3 IC $_{50} 400 \mu \mathrm{g} /$ $\mathrm{mL}$ and $800 \mu \mathrm{g} / \mathrm{mL}$ (Yu et al., 2009). Jamur dewa mempunyai aktivitas 13 sebagai antikanker mengandung $\alpha-(1-$ $6)-; \quad \alpha-(1-4)$-glukan, $\beta-(1-6)-; \beta-(1-3)-$ glukan, $\quad \beta-(1-6)-; \quad \alpha-(1-3)$-glukan (Firenzuoli et al., 2008), ergosterol (Takaku et al., 2001)(Misgiati et al., 2021), blazein (Itoh et al., 2008), blazeispirol B, C, E dan F, ergostane (Hirotani et al., 2002), agaritine (Akiyama et al., 2011). Penentuan aktivitas terhadap sel MCF-7 pada jamur dewa berdasarkan Bioactivity guided fractionation masih belum ditemukan. Sebagai pengujian pendahuluan untuk mendapatkan bahan aktif yang mempunyai aktivitas antikanker sel MCF-7 dilakukan pengujian terhadap beberapa pelarut untuk mengekstraksi bahan aktif yang terdapat pada jamur dewa. Pelarut yang digunakan adalah n-heksana, diklorometana, etilasetat, etanol $70 \%$. Pelarut ini mewakili pelarut nonpolar, semipolar, dan polar. Tujuan penelitian ini untuk uji pendahuluan untuk mendapatkan bahan aktif yang mampu mempunyai aktivitas antikaner sel MCF-7.

\section{METODE PENELITIAN}

\section{MATERIAL}

Bahan uji/ simplisia yang digunakan adalah semua bagian jamur dewa kering https://doi.org/10.33759/jrki.v4i1.231 
diperoleh dari Industri Obat Tradisional Agaricus Sido Makmur, Lawang Malang dengan Surat Keterangan No 592/SKet/ASM/XII/2020. Adapun klasifikasi Agaricus blazei Murill menurut Peck C.H (1893) sebagai berikut:

Devisi : Basidio

Sub devisi : Eumycetes

Kelas : Agaromycetes

Sub Kelas : Holobasidiomycetes

Bangsa : Agaricales

Famili : Agaricaceae

Genus : Agaricus

Spesies/jenis : Agaricus blazei Murill

Sinonim Agaricus blazei Murill adalah Agaricus subrufescens, Agaricus brasiliensis (Kerrigan, W.R., 2008), Jamur dewa, dan Jamur ABM

\section{Alat Dan Bahan}

Alat yang digunakan dalam penelitian ini adalah seperangkat alat maserasi, evaporator, penyemprot noda, pipa kapiler, TLC visualizer (camag), cawan kultur, inkubator $\mathrm{CO} 2$, laminar air flow, sentrifuge, vortex, botol, mikroplate, conical tube, autoklaf, vacum flash, adaptor, hemositometer, mikroskop, ELISA reader panjang gelombang 580 $\mathrm{nm}$

Bahan yang digunakan lempeng silika GF254, anisaldehid, etilasetat, n- heksana, dikloromenata, etanol 70\%, sel MCF-7, DMSO (Dimeti sulfoksida), PBS (Phospat Buffer Saline), Media M199, MTT (3-(4, 5-dimetiltiazole-2il)-2, 5-difeniltetrazolium bromide).

\section{Rancangan Penelitian}

\section{Ekstraksi}

$2 \mathrm{~kg}$ jamur dewa kering halus direndam dengan pelarut n-heksan selama 24 jam sambil diaduk, selanjutnya disaring. Filtrat ditampung, residu ditambah pelarut n-heksan direndam selama 24 jam, disaring. Perendaman akan dihentikan jika filtrat sudah tidak berwarna. Filtrat diuapkan dengan evaporasi sampai diperoleh ekstrak kental. Residu ekstrak n-heksana dilakukan maserasi dengan pelarut diklormetana. Begitu juga untuk residu dikloremetana dilakukan maserasi pelarut etilasetat, serta residu etilasetat dilakukan maserasi dengan pelarut etanol $70 \%$

\section{Identifikasi}

Terhadap ekstrak n-heksana, diklorometana, etilasetat, dan etanol $70 \%$ yang dihasilkan dilakukan kromatografi lapis tipis dengan menggunakan fase diam lempeng silika gel F254, fase gerak n-heksan:etil asetat (4:1). Profil KLT diamati dengan lampu https://doi.org/10.33759/jrki.v4i1.231 
UV $254 \mathrm{~nm}, 366 \mathrm{~nm}$, penampak noda anisaldehid/ asam sulfat $10 \%$.

\section{Aktifitas Antikanker}

Berdasarkan CCRC (2013) metode pengujian aktifitas antikanker adalah sebagai berikut: Sel kanker MCF-7 ditanam pada mikroplate 96 sumuran sebanyak $5.10^{3} \mathrm{sel} /$ sumuran diinkubasi selama 48 jam pada media RPMI. Ditambahkan ekstrak $(0 \mu \mathrm{g} / \mathrm{ml} ; 3,375$ $\mu \mathrm{g} / \mathrm{ml} ; 6,750 \mu \mathrm{g} / \mathrm{ml} ; 12,500 \mu \mathrm{g} / \mathrm{ml} ; 25$ $\mu \mathrm{g} / \mathrm{ml} ; 50 \mu \mathrm{g} / \mathrm{ml})$ dengan co-solvent DMSO (dimetil sulfoksida), selanjutnya diinkubasikan pada $37^{\circ} \mathrm{C}$ dalam inkubator $\mathrm{CO}_{2} \quad 5 \%$ selama 48 jam. Media RPMI dan ekstrak dibuang kemudian sel dicuci dengan PBS (phospat buffer solution). Pada masingmasing sumuran, ditambahkan $10 \mu \mathrm{l}$ preaksi MTT $5 \mathrm{mg} / \mathrm{ml}$. Sel diinkubasikan selama 4-6 jam dalam inkubator $\mathrm{CO}_{2} 5 \% 37^{\circ} \mathrm{C}$. Reaksi MTT dihentikan dengan reagen asam isopropanol $(\mathrm{HCl} 4 \mathrm{~N}$ dan isopropanol; 1:4), digoyang di atas shaker selama 10 menit. Serapan dibaca dengan ELISA reader pada panjang gelombang 550 $\mathrm{nm}$.

Perhitungan $\mathrm{IC}_{50}$

Perhitungan $\mathrm{IC}_{50}$ (sitotoksik) adalah data absorbansi yang diperoleh dari uji sitotoksik dikonversi ke dalam persen sel hidup. Persen sel hidup dihitung menggunakan rumus:

\section{Absorbansi sel dengan perlakuan - Absorbansi kontrol media sel} $\%$ Sel Hidup $=$ $100 \%$

Absorbansi kontrol media sel - Absorbansi kontrol media

Dari data \% sel hidup, dapat dihitung harga $\mathrm{IC}_{50}$ dengan HASIL DAN PEMBAHASAN menggunakan persamaan regresi linier Ekstrak yang dihasilkan berdasarkan yang merupakan hubungan antara \% sel hidup dengan kadar ekstrak/fraksi. ekstraksi bertingkat dari beberapa pelarut didapatkan berat ekstrak terdapat pada tabel 1 


\begin{tabular}{llll}
\hline Berat ABM & Ekstrak & Berat Fraksi (Gram) & \% Rendemen \\
\hline $2 \mathrm{~kg}$ & N-heksan/ H & 19,6234 & $0,9812 \%$ \\
& Diklorometana/D & 17,5765 & $0,8783 \%$ \\
& Etilasetat/ EA & 19,9512 & $0,9972 \%$. \\
& Etanol/ ET & 249,9723 & $12,4981 \%$ \\
\hline
\end{tabular}

Berdasarkan ekstrak yang dihasilkan di atas dilakukan identifikasi dengan plat KLT silika GF254 dan eluen n-
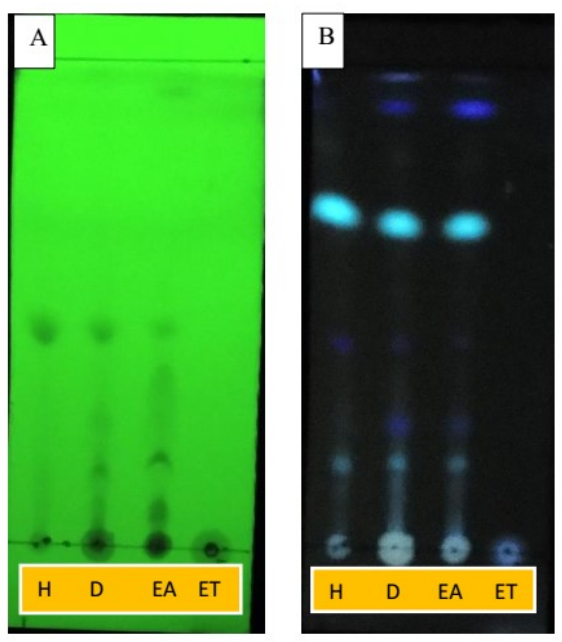

heksana:etilasetat

(4:1). Hasilnya terdapat pada gambar 1 dan 2 di bawah ini
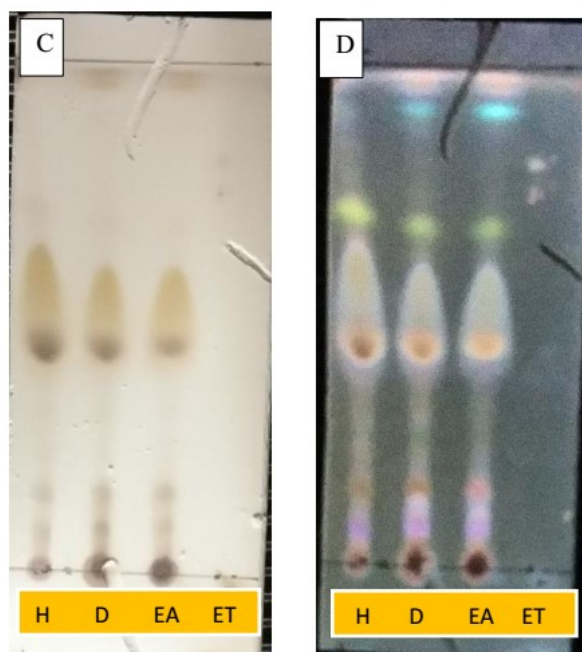

Gambar 1 Kromatogram hasil KLT Ekstrak n-heksan (H), diklorometana (D), etil asetat (EA), dan etanol (ET). Fase diam silika gel $\mathrm{F}_{254}$ dan fase gerak n-heksan:etil asetat (4:1), dan setelah dieluasi dan dilihat dibawah lampu UV $254 \mathrm{~nm}$ (a); di bawah UV 366 (b); setelah disemprot dengan penampak noda $\mathrm{H}_{2} \mathrm{SO}_{4} 10 \%$ dan dipanaskan pada $105^{\circ} \mathrm{C}(\mathrm{c})$; setelah disemprot dan dipanaskan dilihat di bawah lampu UV 366 (d) 

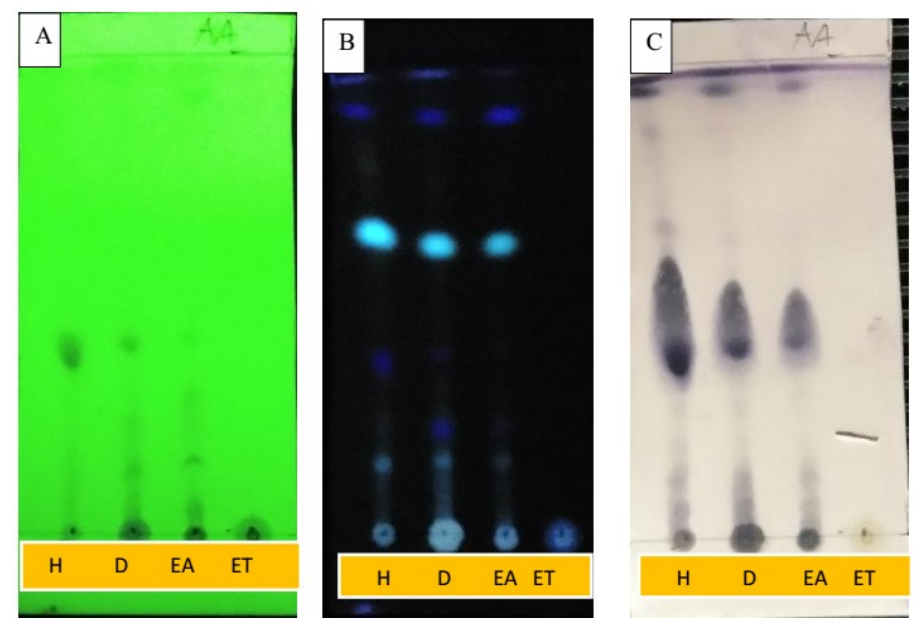

Gambar 2 Kromatogram hasil KLT ekstrak n-heksan (H), diklorometana (D), etil asetat (EA), dan etanol (ET). Fase diam silika $\mathrm{GF}_{254}$ dan fase gerak nheksan:etlasetat (4:1), dan setelah dieluasi dan dilihat dibawah lampu UV $254 \mathrm{~nm}$ (a); di bawah UV 366 (b); setelah disemprot dengan penampak noda anisaldehidaasam sulfat dan dipanaskan pada $105^{\circ} \mathrm{C}$ (c)

Hasil KLT di atas menunjukan adanya metabolit skunder terpenoid, ditunjukkan adanya warna ungu kehitaman setelah di berikan penampak noda anisaldehid, dan coklat kehitaman dengan penampak noda Asam sulfat
10\%. Ekstrak yang dihasilkan dilakukan pengujian aktivitas antikanker sel MCF7. Morfologi sel MCF-7 akibat perlakuan ekstrak tersebut terdapat pada gambar 3 di bawah ini
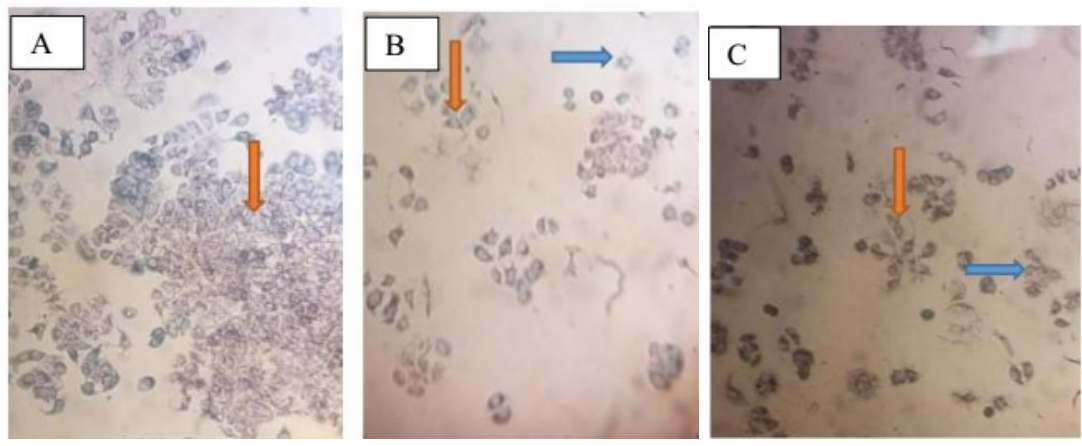


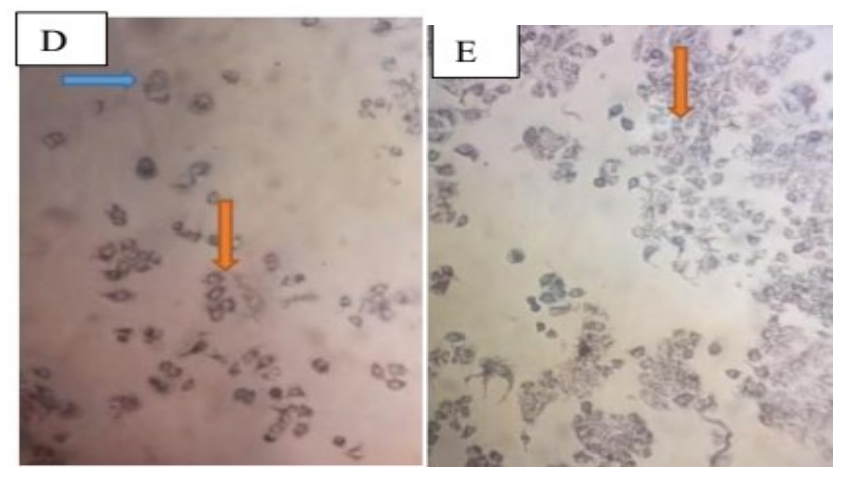

Gambar 3 Hasil aktivitas antikanker karena perlakuan kontrol(A), ekstrak n-heksan

(B), ekstrak diklorometana/DCM (C), ekstrak etil asetat (D), dan ekstrak etanol 70\%(E) pada sel kanker MCF-T dengan metode reduksi MTT. Pada perlakuan ekstrak dengan kematian sel ditandai memudarnya warna MTT ( ), sedangkan sel yang tidak mati ditandai dengan menguatnya warna MTT dan di sekiar sel terdapat serabut-serabut ( ).

Berdasarkan gambar 3 menunjukkan bahwa perlakuan ekstrak n-heksan, ekstrak diklorometana, dan ekstrak etilasetat menyebabkan perubahan morfologi pada sel MCF-7. Pada kontrol sel MCF-7 terjadi sel bergerombol dengan warna MTT intensif serta di sekitar sel terdapat serabut-serabut. Setelah perlakuan ekstrak n-heksan, ekstrak DCM, dan ekstrak etil setat sebagian sel terlepas dan warna MTT pudar. Sedangkan untuk ekstrak etanol terdapat menguatnya warna MTT yang lebih banyak. Hasil aktivitas antikanker ekstrak n-heksan, ekstrak diklorometana, ekstrak etil asetat dan ekstrak etanol yang ditunjukkan nilai $\mathrm{IC}_{50}$, terdapat pada tabel 2 di bawah ini

Tabel 2: Data Hasil Aktivitas Antikanker $\left(\mathrm{IC}_{50}\right)$ Sel MCF-7 Ekstrak n-Heksan, Ekstrak Diklorometana (DCM), Ekstrak Etilasetat (EA),

\begin{tabular}{ll}
\hline Ekstrak & $\mathrm{IC}_{50}$ \\
\hline N-heksan/ H & $15.0923 \mu \mathrm{g} / \mathrm{ml} \pm 0,50$ \\
Diklorometana/ D & $17.4213 \mu \mathrm{g} / \mathrm{ml} \pm 2,23$ \\
Etilasetat/ EA & $10.9132 \mu \mathrm{g} / \mathrm{ml} \pm 0,14$
\end{tabular}


$675,1236 \mu \mathrm{g} / \mathrm{ml} \pm 10,3$

Uji aktivitas antikanker dilakukan secara in-vitro terhadap sel kanker MCF-7. Karakteristik sel kanker MCF-7 adalah mengekspresikan reseptor esterogen (ER+), overekspresi Bcl-2 (Amundson et al., 2000), resisten terhadap agen kemoterapi (Aouali et al., 2003). Hal ini disebabkan karena terjadi over ekspresi PgP (P-glikoprotein), sel MCF-7 membutuhkan ATP untuk mendorong obat keluar sel, sehingga konsentrasi obat kemoterapi dalam sel akan turun dapat menurunkan efektifitas kemoterapi. Sel MCF-7 termasuk cell line adherent yang mengekspresikan reseptor estrogen alfa (ER- $\alpha)$, dan tidak mengekspresikan caspase-3 (Onuki et al., 2003).

Metode yang digunakan pengujian aktivitas antikanker adalah metode MTT. Prinsipnya adalah terjadinya reaksi reduksi garam tetrazolium MTT (3-(4, 5dimetilthiazol-2-il)-2-5-difenil tetrazolium bromide) oleh enzim reduktase dalam mitokondria sel hidup membentuk kristal formazan berwarna ungu yang tidak larut air. Penambahan larutan stopper (Sodium Dedocyl
Sulfate) yang akan melarutkan kristal formazan, selanjutnya diukur absorbansinya dengan menggunakan ELISA reader. Intensitas warna ungu menunjukkan jumlah sel yang hidup, sehingga intensitas warna ungu semakin kuat, jumlah sel yang hidup semakin banyak. Untuk mengetahui nilai $\mathrm{IC}_{50}$ dari masing-masing bahan uji berdasarkan $\%$ sel yang hidup, selanjutnya dihitung dengan analisa probit. Nilai $\mathrm{IC}_{50}$ ini menunjukkan besarnya konsentrasi masing-masing bahan uji yang dapat menghambat 50\% pertumbuhan sel kanker. Menurut Weerapreeyakul et al. (2012) bahan dinyatakan memiliki aktivitas antikanker apabila memiliki nilai $\mathrm{IC}_{50}$ $<10 \mu \mathrm{g} / \mathrm{ml}$ (very strong cytotoxicity), IC50 $\quad 10-100 \quad \mu \mathrm{g} / \mathrm{ml} \quad$ (strong cytotoxicity), dan $\mathrm{IC}_{50} 100-500 \mu \mathrm{g} / \mathrm{ml}$ (moderat cytotoxicity)

Pencarian senyawa aktif antikanker diawali dengan melakukan ekstraksi bertingkat dari beberapa pelarut terhadap jamur dewa kering yang diserbuk. Pelarut pertama yang digunakan n-heksan, selanjutnya residu di ekstraksi berturut-turut dengan 
pelarut diklormetan, etilasetat, dan etanol 70\%. Ekstraksi yang dilakukan dengan metode maserasi. Hasil identifikasi fitokimia masing-masing ekstrak dengan KLT menunjukkan adanya senyawa golongan terpenoid dengan munculnya spot biru keunguan yang menonjol setelah disemprotkan anisaldehid. Pengujian aktivitas antikanker terhadap keempat ekstrak tersebut nilai $\mathrm{IC}_{50}$ seperti yang terdapat pada tabel 2 dari ketiga ekstrak (ekstrak n-heksan, ekstrak diklorometana, dan ekstrak etil asetat) berdasarkan analisa statistik uji F diperoleh nilai sig 0.07 (p $>0.05)$, artinya bahwa perlakuan ekstrak tersebut untuk nilai $\mathrm{IC}_{50}$ tidak ada berbedaan $\left(\mathrm{H}_{0}\right.$ diterima $)$, mempunyai aktivitas antikanker strong cytotoxicity, nilai $\mathrm{IC}_{50}$ pada $10-100$ $\mu \mathrm{g} / \mathrm{ml}$. Hal ini juga ditunjukkan profil KLT pada ketiga ekstrak tersebut mempunyai kemiripan spot. Sedangkan pada ekstrak etanol $70 \% \mathrm{IC}_{50}$ diatas 500 $\mu \mathrm{g} / \mathrm{ml}$, tidak mempunyai aktivitas antikanker pada sel MCF-7. Kandungan ergosterol (Takaku et al., 2001; Misgiati et al., 2021), blazein (Itoh et al., 2008), blazeispirol B, C, E dan F, ergostane (Hirotani et al., 2002) senyawa-senyawa ini yang mempunyai aktivitas sebagai antikanker.

\section{KESIMPULAN}

Berdasarkan hasil di atas adapat disimpulkan

1. bahwa ekstrak n-heksna, dikrlorometana, etilasetat jamur dewa (Agaricus blazei Murill) mengandung senyawa metabolit skunder golongan terpenoid

2. bahwa ekstrak n-heksna, dikrlorometana, etilasetat jamur dewa (Agaricus blazei Murill) mempunyai aktivitas antikanker sel MCF-7 dengan nilai $\mathrm{IC}_{50}$ $15.0923 \mu \mathrm{g} / \mathrm{ml}, 17.4213 \mu \mathrm{g} / \mathrm{ml}$, $10.9132 \mu \mathrm{g} / \mathrm{ml}$ dengan kriteria strong cytotoxicity sedangkan untuk ekstrak etanol $\mathrm{IC}_{50} 675$, $1236 \mu \mathrm{g} / \mathrm{ml}$.

\section{UCAPAN TERIMAKASIH}

Terimaksih kepada Industri Obat Tradisional Agaricus Sido Makmur Sentosa Lawang yang telah memberikan sampel Jamur dewa kering

\section{DAFTAR PUSTAKA}

Akiyama, H., Endo, M., Matsui, T., Katsuda, I., Emi, N., Kawamoto, Y., Koike, T., \& Beppu, H. (2011). Agaritine from Agaricus blazei Murrill induces apoptosis in the https://doi.org/10.33759/jrki.v4i1.231 
leukemic cell line U937. Biochimica et Biophysica Acta, 1810(5), 519-525. https://doi.org/10.1016/j.bbagen.20 11.02.010

Akiyamaa, \& Al, E. (2011). No Title. Biochimica et BiophisicaActa (BBA), 1810(5), 519-525. ttps://www.sciencedirect.com/scien ce/article/abs/pii/S0304416511000 493?via\%3Dihub

American cancer society. (2021). Breast cancer: key statistic of breast cancer. Availableat: http: //www.cancer.org/ cancer/ breastcancer/ detailedguide/ breastcancer-key-statistics diakses pada tanggal 21 Desember 2021

Amundson, S. A., Myers, T. G., Scudiero, D., Kitada, S., Reed, J. C., \& Fornace, A. J. J. (2000). An informatics approach identifying markers of chemosensitivity in human cancer cell lines. Cancer Research, 60(21), 6101-6110.

Aouali, N., Morjani, H., Trussardi, A., Soma, E., Giroux, B., \& Manfait, M. (2003). Enhanced cytotoxicity and nuclear accumulation of doxorubicin-loaded nanospheres in human breast cancer MCF-7 cells expressing MRP1. Int $J$ Oncol, 23(4), 1195-1201. https://doi.org/10.3892/ijo.23.4.11 95

CCRC (Cancer Chemoprevention Research Center). MTT Method Cytotoxic Test Protocol. Yogyakarta: Faculty of Pharmacy, Gadjah Mada University, 2013

Departemen Kesehatan RI., 2019. Hari Kanker Sedunia 2019. Diakses dari https://www.kemkes.go.id/article/v iew/19020100003/hari-kankersedunia-2019.html, pada tanggal 23 November 2020

Firenzuoli, F., Gori, L., \& Lombardo, G. (2008). The Medicinal Mushroom Agaricus blazei Murrill: Review of Literature and Pharmaco-Toxicological Problems. Evidence-Based Complementary and Alternative Medicine: ECAM, 5(1), $3-15$. https://doi.org/10.1093/ecam/nem0 07 https://doi.org/10.33759/jrki.v4i1.231 
Hirotani, M., Sai, K., Hirotani, S., \& Yoshikawa, T. (2002). Blazeispirols B, C, E, and F, desA-ergostane-type compounds, from the cultured mycelia of the fungus Agaricus blazei. Phytochemistry, 59(5), 571-577. https://doi.org/10.1016/s00319422(01)00445-9

Itoh, H., Ito, H., \& Hibasami, H. (2008). Blazin of a new steroid isolated from Agaricus blazei Murrill (himematsutake) induces cell death and morphological change indicative of apoptotic chromatin condensation in human lung cancer LU99 and stomach cancer KATO III cells. Oncology Reports, 20(6), 1359-1361.

https://doi.org/10.3892/or_000001 52

Kerrigan, R.W., Callac, P., dan Parra, L.A. 2008. New and Rare Taxa in Agaricus section Bivalares

(Duploannulati). Mycologia, 100: 876892
Misgiati, M., Widyawaruyanti, A., Sukardiman, \& Raharjo, S. J. (2021). Ergosterol isolated from Agaricus blazei Murill n-hexane extracts as potential anticancer MCF-7 activity. Pharmacognosy Journal, 13(2), 418-426. https://doi.org/10.5530/pj.2021.13. 53

Misgiati M, \& Corebima AD. (2015). Agaricus blazei Murill on the hematological parameter, random blood sugar, total cholesterol, and uric acid of Wistar rats (Sprague Dawley). Journal of Scientific Research and Studies, 2(2), 56-62. http://www.modernrespub.org/jsrs/ index.htm

Onuki, R., Kawasaki, H., Baba, T., \& Taira, K. (2003). Analysis of a mitochondrial apoptotic pathway using Bid-targeted ribozymes in human MCF-7 cells in the absence of a caspase-3-dependent. Antisense \& Nucleic Acid Drug Development, 13(2), 75-82. https://doi.org/10.1089/108729003 321629629 
Peck, C.H. 1893. Report of the Botanist 1892. Annual Report on the New York State Museum of Natural History. 46: 85-149

Shimizu, T., Kawai, J., Ouchi, K., Kikuchi, H., Osima, Y., \& Hidemi, R. (2016). Agarol, an ergosterol derivative from Agaricus blazei, induces caspase-independent apoptosis in human cancer cells. International Journal of Oncology, 48(4), 1670-1678. https://doi.org/10.3892/ijo.2016.33 91

Takaku, T., Kimura, Y., \& Okuda, H. (2001). Isolation of an antitumor compound from Agaricus blazei Murill and its mechanism of action. The Journal of Nutrition, 131(5), 1409-1413. https://doi.org/10.1093/jn/131.5.14 09

Weerapreeyakul, N., Nonpunya, A., Barusrux, S., Thitimetharoch, T., \& Sripanidkulchai, B. (2012).
Evaluation of the anticancer potential of six herbs against a hepatoma cell line. Chinese Medicine (United Kingdom), 7. https://doi.org/10.1186/1749-8546$7-15$

Wu, B., Cui, J., Zhang, C., \& Li, Z. (2012). A polysaccharide from Agaricus blazei inhibits proliferation and promotes apoptosis of osteosarcoma cells. International Journal of Biological Macromolecules, 50(4), 11161120.

https://doi.org/10.1016/j.ijbiomac.2 012.02 .023

Yu, C.-H., Kan, S.-F., Shu, C.-H., Lu, T.-J., Sun-Hwang, L., \& Wang, P. S. (2009). Inhibitory mechanisms of Agaricus blazei Murill on the growth of prostate cancer in vitro and in vivo. The Journal of Nutritional Biochemistry, 20(10), 753-764. https://doi.org/10.1016/j.jnutbio.20 08.07 .004 